\title{
Miranda
}

Revue pluridisciplinaire du monde anglophone /

Multidisciplinary peer-reviewed journal on the English-

speaking world

$23 \mid 2021$

Modernist Exceptions

\section{Mad Method}

Shonni Enelow, In Conversation with Jacob Gallagher-Ross

Jacob Gallagher-Ross

\section{(2) OpenEdition}

\section{Journals}

Electronic version

URL: https://journals.openedition.org/miranda/42939

DOI: 10.4000/miranda.42939

ISSN: 2108-6559

\section{Publisher}

Université Toulouse - Jean Jaurès

\section{Electronic reference}

Jacob Gallagher-Ross, "Mad Method", Miranda [Online], 23 | 2021, Online since 15 October 2021, connection on 29 November 2021. URL: http://journals.openedition.org/miranda/42939; DOI: https:// doi.org/10.4000/miranda.42939

This text was automatically generated on 29 November 2021.

\section{(c) (†) $\ominus$

Miranda is licensed under a Creative Commons Attribution-NonCommercial-NoDerivatives 4.0 International License. 


\title{
Mad Method
}

\author{
Shonni Enelow, In Conversation with Jacob Gallagher-Ross
}

Jacob Gallagher-Ross

\section{Biographies}

1 Shonni Enelow is an associate professor of English at Fordham University and the author of Method Acting and Its Discontents (Northwestern University Press, 2015), which won the George Jean Nathan Award for Dramatic Criticism. A Discourse on Method, a hybrid art book co-authored with David Levine, was published by 53rd State Press in 2020. She is currently working on a book tentatively titled Sweat: A Theory of American Performance.

2 Jacob Gallagher-Ross is an associate professor of English and drama at the University of Toronto, and the author of Theaters of the Everyday (Northwestern University Press, 2018). His article "Mediating the Method" (Theatre Survey, 2015), about Method acting's creative dialogue with recording technology, won the American Theatre and Drama Society's Vera Mowry Roberts Award for the best article of the year. A frequent contributor to theater journals, he was for many years a theater critic for The Village Voice and other US national publications. He's currently collaborating with New York performance company Big Art Group on the first book about their career.

\section{Interview}

\begin{abstract}
Jacob Gallagher-Ross: Shonni Enelow, you're the author of an award-winning scholarly book about Method acting, Method Acting And Its Discontents (Northwestern UP, 2015) which will probably be familiar to many readers of this interview. Now you've revisited the subject from a different angle with a new collaborative volume, A Discourse On Method (53rd Street Press, 2020), written in tandem with the artist and director David Levine. What made you want to return to Method acting? What was your unfinished business with the subject?
\end{abstract}

Shonni Enelow: I don't think I'm ever going to be finished entirely. I think a lot of the questions that Method acting makes particularly pointed, in weird and interesting 
ways, are just long standing questions of modern acting. So insofar as those questions, I think, will engage me for a long time, the focal point of Method continues, for me, to be a way to get to all these bigger questions about what acting is, how we understand it, how we see it, how the spectator sees it, etc.

JGR: This book has a hybrid form. It's part performance text, part memoir, part essay. In what way was the hybrid form of this book suggested by the category confusions of Method acting itself?

SE: The other way to answer your first question is to say that in a practical sense, I also had all this emotional unfinished business with my first book. And to speak to this question that you just raised, that struck me as part of the whole problem of Method in general. Which is that, it's, on the one hand, a method of reading the work of others, of interpreting other people's texts and ideas, and on the other hand, it's supposed to be this technology of self-creation. And so I do think that kind of hybrid autobiography, that autobiographical-critical mode, is very much tied to the actual practices of method acting.

JGR: David Levine's script arose out of a particular performance piece, but what was the genesis of your contribution to the book? How did these texts come about?

SE: My first book came out in 2015, and that summer I met David and we found that we had a lot of similar interests. And he invited me to come to Toronto, where he was showing an installation at Gallery TPW that included the monologue in the book, to do an event with him where we talked about the history of Method acting and how it relates to what he engaged in the installation, these body-snatching movies from the '70s and this sort of secret history of the late 20th century in which Method acting becomes this node of conspiracist thinking. So we did this event, and it was interesting and weird-it was kind of a failure as an event, for interesting reasons. Because we hadn't figured out the form that could successfully contain all these kind paranoiac-slash-cultural-critical epistemologies. And we started sort of plotting some kind of a hybrid book. Then I was on leave, and I went away-I mean, I went away in the sense that I shut myself in my office in my apartment, and started thinking about this bizarre experience that I had had traveling to the Actors Studio archives. And it struck me that that experience was kind of a perfect correlate to these '70s horror movies that David talks about in the installation. And so I started writing it, and the piece expanded to include a lot of material that I couldn't figure out how to fit into the book. So for instance, the stuff about Strasberg and the Golem was just this little thing I had written. And also the stuff about Apocalypse Now. It was almost like David, without knowing it, had been working in his own artwork with all this fringe material that I had excluded from my scholarship, and his engagement with those fringes encouraged me to pick them back up for myself.

JGR: I mean, it's a very Strasberg-esque move to take an event that was kind of unsatisfying in the moment, and then retroactively turn it into something more accomplished. In his case, it was the transcripts of his own acting classes, which became material for his books. So you've done a very Method thing here. There are all kinds of interesting resonances between the two halves of the book but one of them, of course, is this shadow narrative of Heart of Darkness, which arrives via your treatment of the film Apocalypse Now. Were you thinking of your journey to Wisconsin to hear recordings of Strasberg's voice as a kind of Heart of Darkness story? Is he Colonel Kurtz?

SE: You're right, that was the thing I was plagued with. There was a sense in which the trip to the archives was a kind of Heart of Darkness-style search for the true horror 
of Method acting, which is figured by the emotional memory exercise and its exorcism of trauma. I felt compelled to get as close as I could to that.

But also, and this is what I'm struggling a little bit to articulate, it was a journey into the secret truth of my own sense of emptiness as a scholar. Let me put it this way: the voyage at once disguised, but also revealed, the sense that my work is built on this foundation of inauthenticity, that the world of my scholarship has no authentic ground. I think that's what I find compelling in all these post-1960s narratives of journeying into the darkness-the backhanded acknowledgment that the truth you're going to find there is just going to be Marlon Brando taking the piss, like at the end of Apocalypse Now. That even the more baroque and exhausting and strenuous parts of the journey actually only underline that truth, which is that it's a pointless exercise and what you're secretly enjoying is the extended delay of the revelation of its pointlessness.

JGR: I think maybe you told me this, but the Strasberg recordings are housed in Wisconsin, according to lore, because it's equidistant from LA and New York. So they're equally hard to get to for people from LA, and from New York-the two cities where Strasberg did most of his work. So there's something about the trip that already entails a kind of pilgrimage. For you, it arrived at the end of your dissertation research. So it was a kind of summation, it was the journey to confirm all the things that you had suspected about him. But there's this incident that you narrate here, which I know is true because I've talked with you about it in other contexts. While you were in Wisconsin, you got a bad case of food poisoning, and had this kind of bodily crisis. Can you talk a little more about that? It was a coincidence at the time, but it becomes very meaningful in the context of this book.

SE: There's obviously a parallel between me throwing up in this hotel room, and Martin Sheen flipping out on booze and drugs in a hotel room in Saigon at the opening of Apocalypse Now. I was playing with that kind of repetition. It's a kind of literalization of one endpoint of Method: you literally vomit your guts out. I mean, it's a joke in one sense, but there's this map you can draw of scenes of this kind of literalization, you know, and some of them occur, like, for instance, in The Exorcist, and the other movies that David talks about in his monologue that kind of attach themselves to method acting and its tributary phenomena.

JGR: It also seems, in a funny way, to echo one of these moments that occur a lot in Strasberg's books, - and you've written beautifully about this in your other book - where a (usually) female student breaks down in the classroom. And through that physical collapse, some kind of new knowledge is achieved, knowledge which seems to be very tangential to acting pedagogy. But nonetheless, it's really crucial to the work of Method, as Strasberg understands it. Was this your breakdown-to-breakthrough moment?

SE: I mean, it's set up that way, right? But then there's no breakthrough. I just have to drive back to Chicago. It's a deflation right at the end. I think on the one hand that is me voicing the skepticism I have about the mid-century narrative of authenticity. But on the other hand, and I think I allude to this in the final section of the piece, I have a lot of envy for that confidence: that you could really arrive at a revelatory healing breakthrough. Obviously, there are different discourses in the 21st century that hearken back to that belief. But for me, certainly, that isn't available. Faith in that is unavailable. I think in the final section in the piece I express a lot of longing for the moment when that seemed like a viable way of life. 
JGR: Yeah, and for the idea that there might, there might be some justification for all this stuff. I mean, certainly, when you're a scholar working on a long term project...

SE: Oh, there's no catharsis. But I think the realization that there is no catharsis is also implicit in the Actors Studio sessions, right? Because that's the scene where the actors, after their success, go back to the studio the next day and say, you know, I realized it was all empty. And this life practice of returning to the studio enables them to keep alive the flame in a way that that public creation does not, like public display does not, or something?

JGR: Yeah, for those Method stalwarts, it's the scene of the durational engagement at the Actors Studio, that provides the more satisfying learning, the more satisfying art, than anything they're doing out there in the world of commerce, which Strasberg always has contempt for, even though it's what buttresses his reputation. But that makes a really interesting transition to your consideration of the Jewishness of method acting. It was just occurring to me, as we were talking, that we were describing a very Jewish kind of perspective: the suffering of the world must be made to yield meaning, but the meaning will not be satisfying, ultimately, and you just have to keep suffering and keep finding meaning - and that actually all that matters is showing up. Because it's an anti-cathartic structure. So you just have to keep going and have some faith that something will yield through that practice. But it's not a cathartic revelation, even though Strasberg's authority can be a bit rabbinical.

SE: And that's the whole thing about Judaism. It's like, you just have to keep doing the tefillin. Nobody, nobody will ever ask if you believe in God-that is not a question. It doesn't matter. Just keep wrapping your phylacteries every morning.

JGR: Can I ask you more about that? Because this is something you remark on in the book, and it's so true that basically everybody who was involved with getting Method acting started was Jewish, but that's something that was deliberately occluded by those practitioners themselves. And that obfuscation is repeated in the criticism. It's not something that people talk about. You mentioned that you were grappling with it as you did your research.

SE: I think that question sits at the core of a lot of issues of American Jewish identity. It clearly tracks with a narrative of post-war assimilation. But you could also trace it back earlier to the Jewish ambivalence about difference that is so central to modernity and modernism. Freud is an obvious example, but, you know, there are many others. European Jews, as culture producers, in many cases, wanted to speak for everyone, to use the universalist mode. But they also had a certain distance from the idea of the universal. That's just the tension and the history of European Jewry. And it's only very recently that Method acting has been a serious subject of cultural studies scholarship. I hope that somebody will write a serious book about Jewishness and method acting.

JGR: In the book, you have this amazing close reading of two metaphors that between them encapsulate so much of what you're talking about. Speaking of primal themes: on the one hand, there's Strasberg's weird resort to an Egyptian image in one of his books - I mean, you want to talk about primal scenes and suffering. And then on the other hand, you have this great reading of him as the Golem, the archetypal image of Jewish revenge, for lack of a better term. And there's something really interesting about that polarity. On the one hand, the suffering that must be endured and learnt from, and that shapes identity, and then on the other hand, the ultimate triumph for ultimate God.

SE: Totally. I mentioned this really briefly in Method Acting and its Discontents, but it did strike me once you start to look for antisemitic figurations of the Strasbergs 
they're really everywhere, and that's a sort of shadow history of discourse on the Method, too.

JGR: That's so interesting. I can already see the fantasist roots of that - especially the idea that the Strasbergs have an undue influence. They're scheming behind the scenes, they're the ones pulling the strings of the shiksa actor like Marilyn Monroe. The murky presence who is most influential as a teacher, an influencer, less so as an actor or public figure himself. Someone, who's always in the shadows, always always operating in secrecy. The image fulfills so many durable anti-Semitic tropes.

\section{SE: Yeah, there's a lot there.}

JGR: Then Strasberg plays the Jewish mobster in The Godfather and he's totally chilling and brilliant and there's also that one scene where he's kind of putting himself at the center of a movie, at the center of a kind of historical narrative - but I think we just figured out that we have an article to write!

SE: I would love to, that would be great. Our parents would be so happy. Could I actually ask you - I can see connections to the Odets recording that you talk about in your book [Theaters of the Everyday, Northwestern University Press, 2018]. Do you see this nexus of Jewishness that we're talking about in relation to that?

JGR: Yeah, absolutely. I feel like I'm sort of doing the media studies version of the argument that you were just making, which is that with his fixation on that recording, he's trying to say there's something incredibly authentic about these immigrant accents. But he won't say it outright, because he's eliding the Jewishness of those voices. And then in his mind somehow the accent gets linked to the other serendipitous qualities that emerge on the recording - and then it's the recording that ultimately becomes the thing. The recording becomes a displaced image for the immigrant accent. So there's something about his desire to claim an immigrant authenticity that then gets rolled into an uncanny mediatic idea of authenticity. It's really interesting because then both things become important: the capacity of recording to reveal the unconscious of speech, and the fetishization of all kinds of accents. You know, hallmarks of an immigrant identity becoming an important part of what gets revealed by the recording. I'm thinking of early performances by Pacino and De Niro where they're just all in their Italian-American accents and they're relying on the medium of film in a similar way.

I want to ask a little bit more about the form of the monologue, because it's one that's sort of positioned between the different poles of method thinking. You know, on the one hand, it's a kind of medium of confession or unveiling of the self. In the transcripts of the classes, these are often the moments where an actor might have a breakthrough. But at the same time, they're also audition material, right? It's the figure of the lonely exposed object actor doing their monologues for the presumably uncaring casting agent. Both halves of this book are monologues that are in a very different space than those two poles, but how are you thinking about the kinds of monologues that are in the book versus the kind of monologues the method is usually concerned with? Is there a way that you were doing the subtext of your book, in this monologue?

SE: Of my other book? I mean, yeah, I think so.

JGR: Which is so fascinating, because there are all kinds of emotions that attend finishing a book. You talked me through them when I was about to publish mine. You know, the moment near the end where it's like, this is awful. But actually, it's gonna be fine, but you don't know that it's gonna be fine. So you were given the rare opportunity here to actually kind of air some of that...energy?

SE: That's a good way of putting it. Yeah, it's true. These moments when we publish as academics are these combinations of decades of labor but also it's this moment where the ground kind of gives way, and you feel this terror, this existential terror. 
JGR: And it's a moment of performance, right? Like you, you suddenly have an object that will be on this stage. It's a rite of passage.

SE: I do think that there's something about the historical moment we're in that makes those feelings especially piquant. There was a kind of self-assuredness to academic production for a certain number of decades at the end of the 20th century that I don't think exists anymore. There are obviously historical reasons for that. Of course it was in part the self-assuredness of white men who ruined the academy for everybody. But I think there's a certain vertigo now, too. This obviously very privileged position that we both have of being tenured professors at North American universities, you know, there is also the shame that attends that, which is, as I just read in a Joan Copjec book that I'm reading - shame is the moment where you realize that the other's power is groundless, isn't authentic, right? Shame is the moment where you see the other as not having the power that you imputed to the other.

JGR: This sudden apprehension of the groundlessness of that power, which is sort of analogous to the kind of survivor's guilt that a Method actor who got the big break might have, knowing that there were so many people back at the Studio, who were doing similar things that maybe could have also been contenders. It's so interesting to be publishing books about the labor of acting at a moment when the labor of scholarship in academia has come to resemble the casualization and precarity of the labor of acting.

SE: That's clearly structurally the case. I'm also interested in the discursive move, by which, contemporary, or $20^{\text {th }}$ or, to say, 21st century, scholars are interested in talking about us all as actors, and the revival of that metaphor. What does it mean to say we're all actors now?

JGR: I'd really like to ask you more about that. Maybe a bit of a tangent, but I've noticed this a lot. And I always find it unsatisfying, that when people are grappling for a metaphor, often to talk about neoliberalism, basically, and the effects of the neoliberal market, that people want to reach for metaphors of acting, metaphors of performance, through acting, and it always bugs me. I don't totally know why. I think that part of it is a kind of victim blaming in a funny way. And I think that's related to a kind of anti-theatrical thinking. So what is that? Why are we so keen to reach for the metaphor of the actor on the one hand, and why is it such a lousy metaphor?

SE: I think I have a somewhat different take, because I think it's a good metaphor, but for the opposite of what people want it to mean. That imputing acting to our working lives, our neoliberalized working lives, actually evinces this desire to retain an authentic self that would not be exhausted by our work. So when we talk about ourselves as actors, what we're actually doing is protecting a self away from the role. This is what I'm writing about now. What I've realized is that part of why we love to watch actors is because we want to find a self there. We are always fantasizing about the self of the actor. When we call ourselves actors, we're alluding to a fantasy of selfhood that we don't completely believe in.

JGR That is so interesting. Especially in light of what we were just talking about, because I think it also, I mean, it's a conspiracy of a different kind: it invites a simplified idea of the market and labor relations where there's still someone to blame if we trace it back far enough. We'll get the director, the acting teacher, we'll get the people pulling the strings, which maybe is a scene of knowledge that is made impossible, actually, by contemporary economic relations - it pictures this $\mathrm{Oz}$ moment that isn't there.

SE: Yeah, I think that's right. I mean, exactly as you're saying, it rests on a fantasy that there's something outside the scene. 
JGR: Which is a kind of fundamentally humanist fantasy, that we could still be at the middle of it all. I guess, a good question to leave on might be how your two books about Method acting got you thinking about sweat? Why sweat and labor and acting are the next thing that you're going to think about in print.

SE: David has been for a long time, since before we started working together, thinking about acting and work -- acting as work, work as acting, the work of acting. So my path to thinking about this is really through David. But what we've been thinking about both separately and together was the odd fact, the somewhat counterintuitive fact, that the Method performances that are the most lauded tend to be performances in which we see the labor of acting demonstrated before us. That the labor of acting is made palpable to us, and that what we see is the exertion and the strain and the effort involved in acting. So that interests me, you know, why? Why and how effort itself became what it is important for acting to demonstrate. It's not just about the content of art, but also a new idea of the actor that leads sweat to be such a privileged substance.

JGR: Sweat as byproduct and product.

SE: Exactly.

\section{ABSTRACTS}

Interview with Shonni Enelow, author of Method Acting And Its Discontents. The interview was conducted by Zoom, email, and Google Chat in September and October of 2021.

Entretien avec Shonni Enelow, auteur de Method Acting And Its Discontents. L'échange fut conduit via Zoom, mels et Google Chat de septembre and octobre of 2021.

\section{INDEX}

Mots-clés: Méthode (jeu), Strasberg, David Levine, 1970s, université, authenticité, Apocalypse Now, judaïsme, exorcisme, mémoire émotionnelle, travail, théories du complot

Keywords: Method acting, Strasberg, David Levine, 1970s, academia, authenticity, Apocalypse Now, Jewishness, exorcism, emotional memory, labor, conspiracy theories

Subjects: Theater

\section{AUTHOR}

\section{JACOB GALLAGHER-ROSS}

University of Toronto

Associate Professor of English and drama

jacob.gallagher.ross@utoronto.ca 